\title{
Strategy and Implementation Model of Market Orientation and Business Performance for SME of Batik Jambi
}

\author{
Ade Octavia ${ }^{1, *}$ Zulfanetti $^{2}$ Yayuk Sriayudha ${ }^{3}$ \\ ${ }^{1,2,3}$ Fakultas Ekonomi dan Bisnis Universitas Jambi \\ *Corresponding author.Email: octaviafebunja@gmail.com
}

\begin{abstract}
Relationship testing between market orientation and business performance has been widely conducted. The biggest issue is about model development, while the issue related to managerial applications is still very lacking in information, especially for SMEs. This research aims to (1) formulate a market orientation strategy and (2) implement the market orientation strategy that has been formulated to improve the business performance for SME of batik Jambi. The research was conducted in SMEs of batik Jambi in Jambi City. The research is used in a qualitative design. Moreover, the data is analyzed with Resource-Based Analysis (RBV-analysis) and Political, Economic, Social, and Technology analysis (PEST-analysis). This study is also supported by methods of observation, simulation, and in depth-interview. The finding result showed that three capabilities become the advantages of batik Jambi consist of color innovation, motives diversification, and consumer orientation. Besides, it is known that batik Jambi also has some weaknesses related to price competition, technological innovation, and market access. It is hoped that the implications of this research can produce a formula in terms of a strategic policy not only for SMEs of batik Jambi but also for stakeholder and local governments.
\end{abstract}

Keywords: business performance, market orientation, product innovation.

\section{INTRODUCTION}

The market orientation and business performance relationship model has been empirically tested over the past 20 years, which found that there is a positive and significant influence between market orientation and business performance. If grouped, the focus of research on market orientation can be distinguished into four groups that focus on the definition in which research focuses on drafting the concept of market orientation. The fundamental question in research is what is market orientation?. [1][2][3][4]. second, focus on measurement. Research focuses on the development of measurement instruments where the emphasis of the research is how market orientation is formed and can be used [2] [5] [6]. Third, focus on the market-performance orientation model. This research focuses on the antecedents and consequences of market orientation and aims to test the cause and effect of market orientation within the organization [2][5]. This research focuses on managerial approaches to implementing market orientation [7] [4].

This research will focus on the fourth point of implementation, where there is a managerial approach to implementing market orientation. The development of market orientation models for small and medium enterprises (SMEs) through empirical testing has been widely done, the results show that market orientation is very important for improving business performance. Asgar et al [8] found that the market orientation and business environment had a positive relationship to the performance of SME businesses in line with the opinions of Khan and Quaddus [9], where the external environment as a moderator variable the relationship between corporate entrepreneurship and business performance. Especially for newly established companies, the entrepreneurial environment influences business performance through an entrepreneurial 
network of resource acquisition and inter-functional coordination [10][11][12].

Gathungu et al [13] strengthen the model of business environment relations, market orientation, and business performance. Octavia [12] found that market orientation influenced the performance of SME businesses through the business environment. Octavia and Hapszi [14] stated that consumer orientation is an antithesis of business performance, although orientation has no direct effect on business performance. That is, although many studies find a positive relationship between market orientation and business performance, for SMEs the relationship is precisely indirectly through the variable between the consumer orientation. It is necessary to strengthen the SMEs to master several more variables. Octavia et al [15] conducted empirical testing of entrepreneurial training relationships, entrepreneurial orientation, market orientation, and business performance. To improve the business performance of market-oriented SMEs is indispensable. But it is also necessary to improve the ability of SMEs through mentoring and training as well as the importance of insightful entrepreneurial-oriented. Certainly, the model that has been found and has been done empirical testing needs to be applied to SMEs through the managerial aspect. The application of this model will be structured or formulated into a strategic formula and ready to be applied to Jambi batik SMEs.

The entrepreneurial element of women dominates SME batik Jambi. More than $90 \%$ of SMEs of batik Jambi are managed by women. The role of women in entrepreneurship contributes to economic development and well-being [16][17][13]. According to Kozubikova (2016), women are considered entrepreneurial success because they can control and build relationships with partners while male entrepreneurs are successful if they have already found their end goal. Some of the things that play a role in the success of women's entrepreneurship include the ability to stand alone, attitudes to risk, high competitiveness, having an innovation orientation and strategic plan [17][18]. With entrepreneurship, women entrepreneurs want to achieve their goals to be recognized by the environment. Identity and recognition of women will give happiness to themselves personally.

Wolf and Freese [19] observed that for women entrepreneurs, there are several family-related factors. The factors come from a couple who provide practical support, share suggestions or ideas, give expanded entrepreneur networks, encourage and entertain them in difficult times, or give help can exert a positive influence on entrepreneurial outcomes. At the same time, if a partner in the family burdens their partner with domestic affairs responsibilities or intervenes in their business it may have a negative influence on the entrepreneurial outcomes of the woman herself. Thus the business environment supported by family plays a very important role.
The business environment will encourage the emergence of innovation. Some researchers have identified gaps in innovation to improve business performance [20]. It is recommended to entrepreneurs improve business performance to pursue innovation and stay competitive as they operate in an ever-changing environment. In this case, the researchers assert that achieving superior business performance leads to innovation [21]. Based on some empirical testing obtained recommendations for SMEs to be marketoriented, thus business performance is expected to improve, hence the objectives of this research are:

a. To formulate a market orientation strategy by analyzing the internal and external environment of Jambi Batik SMEs.

b. To implement market orientation strategy through marketing programs, budgets, and procedures to improve business performance.

\section{METHOD}

Consistent with the problems and objectives of the research, the qualitative design is the most appropriate approach to getting answers to research problems. A qualitative approach using strategy analysis approach by scanning the internal and external environment of SMEs. Based on this scanning will be formulated the right strategy for improving the business performance of SME batik Jambi. Furthermore, the strategy will be implemented to SMEs batik Jambi through simulation approach and FGD together with the government and SMEs batik Jambi themselves.

\section{DISCUSSION}

The Resource-Based View approach looks at the external and internal aspects of the company. The company's view based on internal conditions and resources is a key factor in the company's success in winning the competition. Resource-Based View (RBV) is an approach to achieve a competitive advantage whereby organizations must focus on the organization to find a source of competitive advantage. Resources are allowed to play an important role in achieving the highest corporate excellence.

\subsection{Externally Driven}

\subsubsection{Economic Environment.}

Economically, the number of SMEs of batik Jambi is increasingly widespread. Moreover, the government has launched a national batik day that is on October 2nd. Jambi batik products as one of the fashion products going forward will be increasingly in demand, even starting to be liked by teenagers and millennials. The growing 
market demand for more varied batik models makes it a challenge for Batik Hajir to always innovatively develop it. Some of the ways are done, among others, by participating in various pieces of training carried out by local governments and Universities.

\subsubsection{Market requirements.}

Batik Jambi has a market that covers inside and outside Jambi City. According to its consumers, the products have more durability if compared to Javanese batik. But in research instruments, the quality is not in the same group. Although Javanese batik is available more than Jambi batik it is offered in the market with different artificial qualities. Similarly, batik Jambi, so this result has not been able to infer the durability of a product better than other products. Javanese batik has more different patterns and models than batik from Jambi. The average consumer perception shows for the indicator of Javanese batik pattern and model value is higher compared to Jambi's batik. The influence of Javanese batik is divided into two, namely, deepening batik (Solo, Yogya) and coastal batik (Cirebon, Lasem, Madura, Tuban, and others). The classification is based on the geographical indication environment (culture) and pattern of motifs. Coastal batik is a batik from outside the outer areas of the palace, free, without being tied to the natural benchmarks of the magical religious mind, feudalism, and technical pranata-pranata, coastal batik patterns are more spontaneous, rough, and free both the pattern and the color than the batik from the palace.

Batik Jambi tends to be easy to order because it is close to the location of the respondent which is in Jambi City. This order is made especially if the purchase is in large quantities and consumers want certain motifs and colors that are not widely available in the market. Javanese batik is also easy to order but differently. Consumers have complete information about where to order Javanese batik. Moreover, every region in Java has this industry such as in Solo, Yogya, Cirebon, Semarang, Tuban, and others. Jambi batik delivery is faster than Javanese batik, given that the order is made close to the respondent's place. Batik delivery system is done through the delivery of goods, delivered directly by manufacturers/craftsmen, and so on. Today's online ordering system is also an option that makes it easier for consumers to get products.

Batik is a cultural product so often consumers are interested to know more about the philosophy contained in it. The price of batik also varies depending on the quality of the material, type of batik (write or stamp), size, or color. Thus often consumers ask the craftsman or batik seller. So the seller and employee of the store are required to know about it. In this study, Jambi's batik sellers were more able to consult with consumers compared to Javanese batik sellers.

\subsubsection{Competitors}

Today Batik Jambi has become integrated with people's lives, which can be seen with the growing batik industry and become a Joint Business Group or center. Currently, the number of Jambi batik craftsmen in Jambi City alone amounts to 102 business units and has absorbed a workforce of 1100 people with a production value of Rp. 6,661.7 billion. Currently, in Jambi Province, there are more than 1,500 batik craftsmen with more than 100 batik entrepreneurs. About 80 percent of them are in Jambi City. But of the overall craftsmen and batik businesses, few have established the overseas market as the target market. In fact, as a product of Indonesian culture, batik crafts have uniqueness and characteristics that can be offered abroad. Compared to batik originating from central Java (especially Pekalongan), Jambi batik is still left behind. Good judging by the production factor, expertise, and creativity, sales rate, number of enthusiasts even to penetrate overseas markets. Many factors must be prepared, from the role of the government to the internal and external marketing environment of the batik business itself. Although national and international events have been followed to introduce batik from Jambi among business people, consumers at home, and consumers abroad, the impact has not been seen significantly for the development of Jambi's batik business to increase market share. It should be underlined that export markets provide promising opportunities. Based on the data, there was a $36.46 \%$ increase in batik exports which means that there is considerable foreign market demand for batik. The problem is many batik entrepreneurs, especially batik Jambi's craftsmen who have not been encouraged to direct their marketing strategy to overseas markets. Whereas in the era of globalization and free trade today it is not impossible to penetrate foreign markets. With the right strategies, strong business capabilities, and support from the government, directing of batik from Jambi's products to overseas markets can be realized.

\subsection{Internally Driven}

\subsubsection{Stakeholders Demand}

Javanese batik has more special outlets selling batik if it compared to Jambinese batik's outlet. This is certainly worth the attention because in the batik producing area itself there are still few special outlets selling Jambi batik. Based on observation, Javanese batik is more scattered especially for the type of finished clothing that can almost be found in some places. Jambi's batik special outlets are in Dekranasda, Mirabela, Mentari, and several other small boutiques. Thus, it suggests opening the outlets or shops specialized in Jambi batik sellers to make it easier for consumers to find the product. This is also related to the next indicator that products are easy to find in many places. Javanese batik 
is easier to find in many places compared to Jambinese batik. Not only in special outlets/shops selling batik only but in malls or public shops can also be found Javanese batik. While consumers find it is difficult to find Jambi batik in malls or shopping centers or public shops, Jambi batik is only available in special outlets or Jambi batikmaking centers.

Online purchases are sometimes made by consumers to make it easier for them to get batik from Jambi. Javanese batik is more common in online shopping sites compared to Jambi batik. While from the diversity of products and designs of Jambinese batik can compete with Javanese batik. However, in terms of technology mastery, Javanese batik entrepreneurs are more mastery than Jambi batik entrepreneurs. Thus, it is necessary to increase the technology mastery capability especially the internet for Jambi batik entrepreneurs to be able to make the most of business opportunities through an online marketing system

\subsubsection{Resources}

The color of Jambi batik is more and interesting compared to Javanese batik. Batik from Jambi often uses bright colors such as red, orange, blue, and green. The use of natural ingredients from plants as dyes makes the results look natural and describes the nuances of nature. As Sepang wood produces a reddish yellow color, ramelang wood produces a brownish-red color, slow wood produces yellow color and Nilo wood produces a blue color. The basic fabric materials used by batik craftsmen in Jambi city are silk, cotton, pineapple fiber, shantung, and parsimony. Some batik craftsmen in Jambi still use natural dyes, with the aim that the color of batik is not easily faded. The natural dye comes from plants that only exist in Jambi province. These colors are traditional colors of Jambi batik, which has a distinctive charm that is different from chemical dyes

Jambi batik design and motif are mostly taken from the form of flora and fauna. The uniqueness of Jambi batik lies in the simplicity of the motif form that is the form of a stand-alone motif. Another uniqueness is the name on the Jambinese batik motif given to every form of motif, such as cape bungo motif, jasmine flower motif, cheerful motif, and so on. Although the name is given on each form of motif consisting of one form but in its application does not consist of one form of motive only. At first, the motifs applied Jambi batik in the form of ornamental motifs such as seen in the carving of Jambi traditional house and on the wedding clothes. Today the resulting motives are more diverse and rich in local cultural philosophy

\subsubsection{Competencies}

The seller's knowledge of the quality of batik products sold is quite good, although according to consumers Javanese batik sellers have more knowledge about the quality of batik compared to Jambi batik sellers. Generally, consumers will ask about the basic ingredients used, whether it is easy to fade or not, the quality of the seams, and how long usually the product is still in good condition. Usually, the basic fabric used by batik craftsmen in the form of silk, cotton, pineapple fiber, shantung, and parsimony.

The hospitality and courtesy of batik sellers when explaining the quality and type of products that consumers want is also a value for customers. The value of consumer perception shows a small difference in value, nevertheless, Javanese batik sellers are judged to be more friendly and courteous in serving consumers.

Furthermore, consumers judge that Jambi batik sellers are more responsive in serving consumers compared to Javanese batik sellers even though the difference is small. The seller's response is evident from an attitude that can quickly respond to what the customer needs, e.g. asking what product to look for, helping to show the location of the product display, and providing an alternative design and color that can be the consumer's choice. For consumers, this responsiveness is very helpful for consumers to find products quickly.

\subsection{Strategies Implemented}

\subsubsection{Operational Excellence}

Batik from Jambi has the advantage in terms of color and motif. As development of Jambi culture, Jambi's batik motif has a unique difference and is characteristic of Jambinese people. The existence of Jambi batik can be an introduction to Jambi culture as the embodiment of the local wisdom of its flora and fauna that dominates the motifs on Jambi batik. Thus strengthening the promotion of Jambi batik to other regions and countries is indispensable. Not only will this promotion be able to improve Jambi's image in the eyes of other regions or countries, but the impact will also be felt by Jambi batik craftsmen.

\subsubsection{Customer Intimacy}

Perception is the process by which a person selects, organizes, and interprets information. When consumers collect information about products with high engagement, they will follow the hierarchy effect. Exposure to a piece of information such as advertising or information from a friend, attracting attention, then understanding and ultimately retention in memory. Once consumers have fully perceived information, they use it to evaluate alternative brands and decide which to buy. Perception processes differ for products with low levels of visibility. Here consumers store information in their memory without going through the stages of attention and conversation. Exposure can cause consumers to 
retain enough information so they are familiar with a brand when they see it in store.

\subsubsection{Product Leadership}

From variables image, Jambi batik is more superior to Javanese batik, while Javanese batik has a higher value for the product, service, personnel, and distribution channels. This is an implication that consumers do not see the fundamental difference between Jambi batik and Javanese batik, making it difficult for Jambi batik to position Jambi batik into something different. Batik has become an identical Javanese product even becoming a symbol of the nation's culture. Long before Jambi and other regions moved the batik industry, Javanese batik was well known everywhere. Repositioning Jambi batik still requires strengthening on the aspects of what consumers think has a distinctive difference with Javanese batik.

\section{CONCLUSION}

Batik from Jambi has the advantage in terms of color and motif. As the development of Jambi's culture, the Jambinese batik motif has a unique difference and is characteristic of people in Jambi. The existence of Jambi batik can be an introduction to Jambi culture as the embodiment of the local wisdom of its flora and fauna that dominates the motifs on Jambi batik. This difference in perception suggests that the same marketing strategy and elements of the program cannot be used to market products or services with high engagement versus low engagement. Batik entrepreneurs should strive to increase consumer engagement with their products as a way to increase their income.

\section{ACKNOWLEDGMENT}

Thanks are given to the Universita Jambi, which has provided these research grants.

\section{REFERENCES}

[1] K.A. Kohli, dan J.B. Jaworski, Market Orientation: The Construct.Research Proposition and Managerial Implication, Journal of Marketing, 1990, 54: 1-18.

[2] J.C. Narver, \& S.F. Slater, The Effect of a Market Orientation On Business Profitability. Journal. Sagepub.com, 1990, Vol. 54 Issue.4.

[3] R.W. Ruekert, Developing a market orientation: An organizational strategy perspective. International Journal Of Research In Marketing, 1992, Vol. 9 issue 3.
[4] G.S. Day, The Capabilities of Market-Driven Organization. Journal of Marketing, 1994, 58(4), pp. 37-52.

[5] K.A. Kohli, J.B. Jaworski, dan A. Kumar, MARKOR: A Measure of Marketing Orientation. Journal of Marketing Research, 1993 30:467-777.

[6] R. Deshpande, J. Farley, and F. Jr. Webster, "Corporate Culture, Customer Orientation, and Innovativeness in Japanese Firms: A Quadrad Analysis", Journal of Marketing, 1993, 57(1), pp. 23-27.

[7] W. Biemans, Overcoming The barriers to MarketOriented Product Development. Journal Of Marketing Practice: Applied Marketing Science, 1995, Vol 1(2) pp 7-25.

[8] A. Asgar, H. Alipour, \& M. Hasanzadeh, Market Orientation and Business Performance Among SMES Based in Ardabil Industrial City-Iran. Kuwait Chapter of the Arabian Journal of Business and Management Review, 2013, Vol.2, No.7.p.38-47

[9] E.A. Khan, \& M. Quaddus, Examining The Influence of Business Environment on Socioeconomic Performance of Informal Microenterprises. Content Analysis and Partial Least Square Approach. International Journal of Sociology and Social Policy, 2015 Vol.36.No.3/4.pp.273-288.

[10] Li. Cai, Z. Xiumei, C . Qiguo, \& Zhou. Di, Research on The Affecting Mechanism of Entrepreneurial Environment on New Firm Performance. Journal of Chinese Entrepreneurship, 2009, Vol.2.No.2.pp. 116-128.

[11] A.N. Balas, , O. Gokus, \& S.N. Colakoglu, Exploring The Role of External Environment on Determining Strategic Focus, Market Orientation, and Firm Performance of Service Firm Academy of Marketing Studies Journal, 2014, Vol.18. No.1

[12] A. Octavia, Influence Models Of Entrepreneurial Orientation, Entrepreneurship Training and Business Performance of Small Medium Entreprises. Advances Science Letters, 2017, Vol 23 (8). $7232-7234$

[13] J. Gathungu, D.M. Aiko, \& V.N. Machuki, Entrepreneurial Orientation, Networking, External Environment, and Firm Performance: A Critical Literature Review. European Scientific Journal, 2014, Vol 10 (7).

[14] A. Octavia, \& A. Hapszi, The Model of Market Orientation, Entrepreneurial Orientation and Business Performance of Small Medium 
Entreprises. International Review of Management and Marketing, 2017, Vol 7(3). 331-337

[15] A. Octavia, Zulfanetti \& Erida. Meningkatkan Daya Saing Daerah Melalui Peningkatan Kinerja Bisnis Usaha Mikro, Kecil dan Menengah di Provinsi Jambi. Jurnal Perspektif Pembiayaan dan Pembangunan Daerah, 2017, Vol 4 (3). 155-166.

[16] S. Nichter, \& L. Goldmark, Small firm growth in developing countries. World Development, 2009, 37(9), 1453-1464. https://doi.org/10.1016/j.worlddev.2009.01.013

[17] C. Doss, Intra Household Bargaining and Resource Allocation In Developing Countries. The World Bank Research Observer, 2013, 28(1), 52-78.

[18] S. Agarwal, V. Agrawal, \& A.M. Agrawal, Motivational and Success Factors: Through The Lens Of Women Entrepreneurship. Int. J. Management and Enterprise Development, 2018, Vol. 17, No. 4, 2018307.

[19] Wolf, K., \& M. Frese, Why husbands matter: Review of spousal influence on women entrepreneurship in sub-Saharan Africa, Africa Journal of Management, 2018 DOI: 10.1080/23322373.2018.1428019.

[20] C. Camisón, \& A. V. Villar López, An examination of the relationship between manufacturing flexibility and firm performance: The mediating role of innovation. International Journal of Operations \& Production Management, 2010, 30, 853- 878. https://doi.org/10.1108/01443571011068199.

[21] E. Byukusenge, \& J.C. Munene, Knowledge management and business performance: Does innovation matter? Cogent Business \& Management, 2017, 4: 1368434. 